\title{
Flow cytometry and sorting of meiotic prophase cells of female rabbits
}

\author{
J. K. Larsen, A. G. Byskov* and I. J. Christensen \\ The Finsen Laboratory, The Finsen Institute, Strandboulevarden 49, DK-2100 Copenhagen, \\ Denmark
}

\begin{abstract}
Summary. We present a new, flow cytometric method by which cells in various stages of the meiotic prophase can be quantitated and sorted in partly enriched fractions. Ovarian cells of 3-16-day-old rabbits were mechanically dispersed and fixed in ethanol and aldehydes. The cell suspension was stained with the DNA fluorochrome mithramycin and analysed and sorted in a FACS IV cell sorter according to the fluorescence and forward light scatter distribution. Cells sorted onto slides were stained with haematoxylin and eosin and differentially counted in the microscope. In the diploid fraction, preleptotene cells were more fluorescent than somatic cells. Leptotene cells were found throughout the $\mathbf{S}$ fraction and the tetraploid fraction. Zygotene and pachytene cells caused a major peak in the tetraploid region with $10-25 \%$ more fluorescence than somatic cells. Cells in diplotene had 5-15\% more fluorescence than somatic cells. Mitotic cells were $20-40 \%$ more fluorescent than somatic cells and scattered the light more intensely than did meiotic cells with the same fluorescence.
\end{abstract}

\section{Introduction}

Quantitative DNA analysis by flow cytometry has been introduced as an alternative and supplement to the cytological and histological examination of mammalian testicular tissue and spermatozoa (Clausen, Purvis \& Hansson, 1977; Meistrich, Lake, Steinmetz \& Gledhill, 1978; Pfitzer, Gilbert, Rölz \& Vyska, 1982; Evenson, Higgins, Grueneberg \& Ballachey, 1985; van Kroonenburgh, Beck, Scholtz, Hacker-Klom \& Herman, 1985), but has rarely been used to examine ovarian tissue and oocytes (Larsen, Byskov \& Grinsted, 1981; Westergaard, McNatty, Christensen, Larsen \& Byskov, 1982; Byskov et al., 1983).

To advance investigations on the humoral regulation of the onset of meiosis by inducing and inhibiting substances during the early development of mammalian ovaries (Byskov, 1979), we searched for a fast assay with which to quantify the proportion of cells that have entered the meiotic prophase (Larsen, Byskov, Yding Andersen \& Christensen, 1982).

In this paper we present a flow cytometric method to discriminate and sort meiotic and mitotic cells on the basis of a combined fluorescence and light scatter analysis of cells previously fixed with ethanol and formaldehyde/glutaraldehyde and stained with mithramycin, a fluorochrome known to bind quantitatively to DNA (Crissman \& Tobey, 1974; Crissman, Stevenson, Kissane \& Tobey, 1979). The immature rabbit ovary was chosen because it is rich in germ cells and because the meiotic prophase, which starts at the time of birth, has been well studied (Peters, Levy \& Crone, 1965; YoungLai \& Byskov, 1983). Furthermore, a suspension enriched in germ cells can easily be squeezed out of the ovary, and the size of this cell population is sufficient for flow cytometric and sorting studies.

*Present address: Laboratory of Reproductive Biology II, Department of Gynecology and Obstetrics, Rigshospitalet, DK-2100 Copenhagen, Denmark. 


\section{Materials and Methods}

Preparation. Female rabbits of the Ssc:CPH strain from Statens Seruminstitut, Copenhagen, were used. The day of birth was considered as Day 0. The animals were decapitated and the ovaries transferred to ice-cold Hanks balanced salt solution (Hanks \& Wallace, 1949). The ovaries were gently squeezed and the freed cells from both ovaries were collected with a siliconated glass pipette in $1.0 \mathrm{ml}$ Hanks solution, and this was added to $0.5 \mathrm{ml}$ ice-cold EGTA buffer $(100 \mathrm{~mm}$-Tris, $10 \mathrm{~mm}-\mathrm{EGTA}, \mathrm{HCl}$ to $\mathrm{pH} 7 \cdot 4)$. The cells were suspended by gentle pipetting and fixed in 2 steps by adding $0.5 \mathrm{ml}$ ice-cold $96 \%$ ethanol followed by $0.5 \mathrm{ml}$ ice-cold Karnovsky's fixative (4\% formaldehyde and 5\% glutaraldehyde in cacodylate buffer at $\mathrm{pH} 7.2$ (Karnovsky, 1965)). By the first step the ethanol concentration was raised to $25 \%$, and by the second step the concentration of formaldehyde was raised to $0.8 \%$ and of glutaraldehyde to $1.0 \%$. Immediately after addition of each fixative, the sample tube was inverted a few times, and the sample was passed through a siliconated pipette to make a single cell suspension. After fixation for $60 \mathrm{~min}$, during which the sample was inverted several times, the sample was centrifuged $\left(120 \mathrm{~g}, 4^{\circ} \mathrm{C}, 5 \mathrm{~min}\right)$. The sedimented cells were resuspended in a mixture of EGTA buffer and $154 \mathrm{mM}-\mathrm{NaCl}$ solution $(1: 9, \mathrm{v} / \mathrm{v})$, and then pipetted and stored at $4^{\circ} \mathrm{C}$. Next day, the fixed cell suspension was vortexed and filtered through a $30 \mu \mathrm{m}$ nylon mesh (Scrynel NY 30 HC, Züricher Beuteltuchfabrik, Rüschlikon, Switzerland).

Flow cytometry and sorting. The filtered cell suspension was stained by addition of mithramycin (Mithracin: Pfizer Inc., New York, U.S.A.) to a concentration of 20 or $100 \mu \mathrm{g} / \mathrm{ml} ; \mathrm{MgCl}_{2}$ was added to a concentration of $25 \mathrm{~mm}$. After a staining period of $15 \mathrm{~min}$ to $3 \mathrm{~h}$, the samples were analysed in a FACS IV cell sorter (Becton Dickinson FACS Systems, Sunnyvale, CA 94086, U.S.A.) equipped with a $70 \mu \mathrm{m}$ flow nozzle and using the $457 \mathrm{~nm}$ argon laser line at $100 \mathrm{~mW}$ for excitation of mithramycin. Forward low angle light scatter and fluorescence $>470 \mathrm{~nm}$ were simultaneously measured.

Droplets with cells fulfilling various dual parameter settings of fluorescence and light scattering were electrically charged and collected by electrostatic deflection on slides for microscopy. One sorting sequence was performed per rabbit. The number of sorting windows applied (3-12) was dependent on the number of ovarian cells that could be sampled from a single rabbit, i.e. dependent on rabbit age. For comparison of the various sorting sequences we found it useful to express the lower and upper level co-ordinates of the sorting windows relative to the co-ordinates of the dominating peak (1a) in the analysed cell population. From these data, we have selected those windows from which the sorting gave maximal relative concentration of the various stages (Table 1).

Single parameter fluorescence histograms were statistically deconvoluted to obtain fractions as illustrated in Fig. 1, using a computerized maximum likelihood estimation procedure (Christensen et al., 1978; Vindeløv, Christensen, Jensen \& Nissen, 1983). The degree of polynomial describing the $S$ phase was set to zero. A peak (2a) was fitted at twice the fluorescence of the dominating peak (1a). Together with a supplementary peak ( $1 \mathrm{~b}$ ) the $S$ fraction was fitted between peaks la and $2 a$, and 1-3 further peaks were fitted into the region (2b) with fluorescence higher than that of 2a. Measurements on samples stained with each dose of mithramycin were pooled, because no statistically significant difference in fluorescence was found in a preliminary experiment.

Microscopy. Cells sorted onto slides with the FACS IV, as well as smears of the fixed cell suspensions without stain for flow cytometry, were dried, postfixed in $70 \%$ ethanol-ether $(1: 1, v / v)$, stained with haematoxylin and eosin and scored differentially in the following categories: interphase, mitotic and pycnotic cells (germ cells and somatic cells), and germ cells in preleptotene, leptotene, zygotene, pachytene and diplotene stages. The slides were coded for counting in a 'blind' manner. It was not possible throughout all series of preparations to distinguish between preleptotene and early mitotic prophase, or to decide whether interphase and mitotic cells belonged to the germ line cells or the somatic cells. In the sorted cell fractions, between 40 and 1359 cells were 


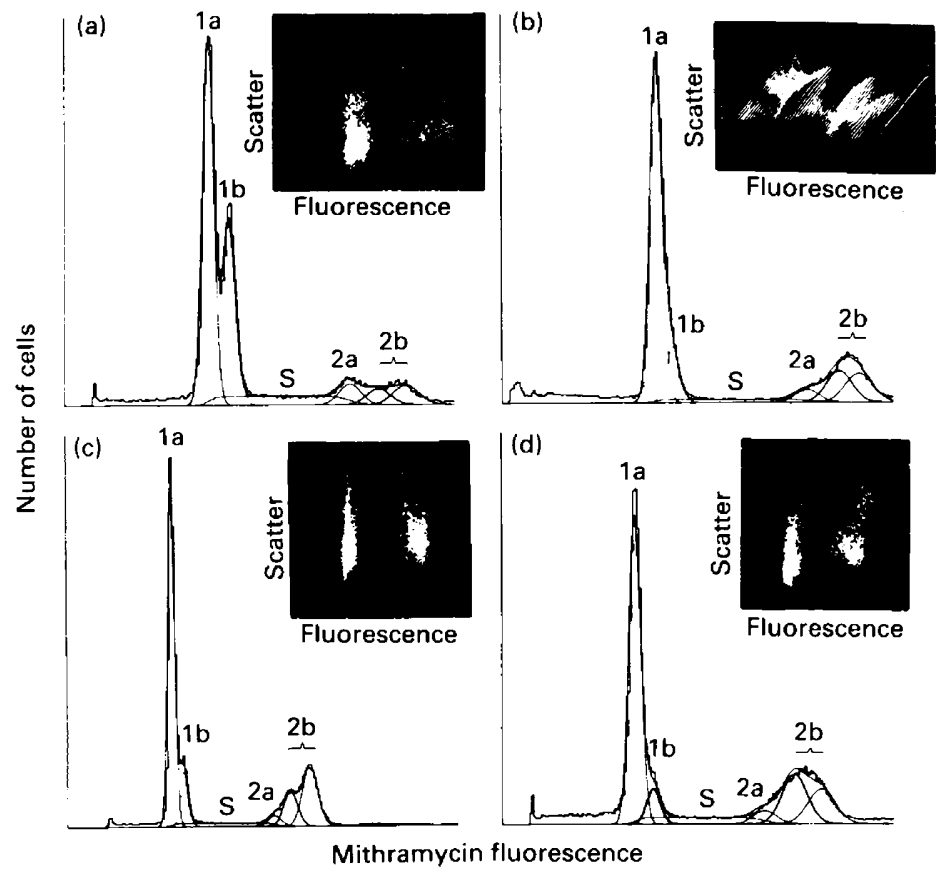

Fig. 1. Flow cytometric analysis of ovarian cells of rabbits at Days 5 (a) and 9 (b, c, d) after birth. Cell suspensions were fixed with ethanol and formaldehyde/glutaraldehyde and stained with mithramycin. Average values of the fractions $1 \mathrm{a}, 1 \mathrm{~b}, \mathrm{~S}, 2 \mathrm{a}$ and $2 \mathrm{~b}$, estimated by a computerized method, are shown in Table 2 . For (c) $4.2 \%$ of the cells were in diplotene, $0.8 \%$ in mitosis and for (d) $0.8 \%$ of the cells were in diplotene, $8.6 \%$ in mitosis.

scored; in smears, 515-1814 cells were evaluated. Preliminary experiments showed that without fixation cells rapidly lost their cytoplasm. Cells sorted without fixation could therefore not be differentially identified under the microscope. Fixation with Karnovsky's fixative before sorting was necessary to conserve the morphology for differential microscopy. The first step of fixation with ethanol prevented clumping of cells, which occurred if they were fixed only with Karnovsky's fixative.

\section{Results}

When flow cytometric fluorescence analysis was extended with simultaneous measurement of forward light scatter, it was possible to obtain a 2- to 50-fold enrichment in relative concentration of specific meiotic stages by using the FACS IV for sorting at appropriate gates in both fluorescence and light scatter (Table 1). However, as illustrated in Fig. 2, the distributions of the different division stages overlapped. From 10 to $70 \%$ of the cells in a given stage fell within the sorting windows that resulted in 2-50-fold enrichment in relative concentration of that stage.

Fluorescence histograms of the ovarian cells measured by flow cytometry after fixation with ethanol and formaldehyde/glutaraldehyde and staining with mithramycin are shown in Fig. 1 . The histogram peaks demonstrate significant heterogeneity $(1 a-1 b$ and $2 a-2 b)$ indicating the influence of characteristics other than DNA quantity. When the fluorescence distribution (Table 2) was compared with the distribution of cell division stages according to morphological criteria (Table 3; Figs $3 \& 4$ ), the increase in fluorescence histogram fraction $2 b$ from Day 5 to Day 9 after birth 
Table 1. Enrichment of the relative concentration of various meiotic and mitotic cell division stages by sorting with the FACS IV according to dual parameter criteria in fluorescence and forward light scatter

\begin{tabular}{|c|c|c|c|c|c|}
\hline \multirow{2}{*}{$\begin{array}{l}\text { Cell } \\
\text { division } \\
\text { stage }\end{array}$} & \multirow{2}{*}{$\begin{array}{l}\text { Days } \\
\text { after } \\
\text { birth }\end{array}$} & \multirow{2}{*}{$\begin{array}{l}\text { No. of } \\
\text { rabbits }\end{array}$} & \multicolumn{2}{|c|}{$\begin{array}{l}\text { FACS IV sorting window } \\
\text { (lower and upper discriminator } \\
\text { levels relative to peak la) }\end{array}$} & \multirow{2}{*}{$\begin{array}{l}\text { Relative } \\
\text { concentration } \\
\text { in sorted } \\
\text { preparation } \\
\text { (\% purity) }\end{array}$} \\
\hline & & & Fluorescence & Light scatter & \\
\hline \multirow[t]{3}{*}{ Leptotene } & 3 & 1 & $\begin{array}{l}1.3-1.9 \\
1.9-2.5\end{array}$ & & $\begin{array}{l}36 \\
30\end{array}$ \\
\hline & 5 & 2 & $2 \cdot 0-2 \cdot 5$ & $1 \cdot 1-1 \cdot 5$ & $23-27$ \\
\hline & 89 & 3 & $\begin{array}{l}1 \cdot 1-1 \cdot 6 \\
2 \cdot 2-2 \cdot 5\end{array}$ & $1 \cdot 1-1 \cdot 5$ & $\begin{array}{l}29-66 \\
48-52\end{array}$ \\
\hline Zygotene & $8-9$ & 3 & $2 \cdot 2-2 \cdot 5$ & $0 \cdot 7-1 \cdot 1$ & $45-71$ \\
\hline Pachytene & $8-9$ & 5 & $2 \cdot 2-2 \cdot 5$ & $0 \cdot 7-1 \cdot 1$ & $23-43$ \\
\hline \multirow[t]{2}{*}{ Diplotene } & $8-9$ & 4 & $2 \cdot 1-2 \cdot 3$ & $1 \cdot 4-2 \cdot 4$ & $6-49$ \\
\hline & 16 & 1 & $2 \cdot 1-2 \cdot 3$ & & 44 \\
\hline \multirow{2}{*}{$\begin{array}{l}\text { Zygotene }+ \\
\text { pachytene }+ \\
\text { diplotene }\end{array}$} & $8-9$ & 6 & $2 \cdot 1-2 \cdot 5$ & $0 \cdot 8-1 \cdot 4$ & $40-94$ \\
\hline & 16 & 1 & $2 \cdot 2-2 \cdot 3$ & & 68 \\
\hline Mitosis & $8-9$ & 3 & $2 \cdot 4-2 \cdot 8$ & $1 \cdot 6-2 \cdot 8$ & $5-37$ \\
\hline $\begin{array}{l}\text { Interphase } \\
\text { doublet cells }\end{array}$ & $8-9$ & 2 & $1 \cdot 8-2 \cdot 1$ & $1 \cdot 6-2 \cdot 8$ & $54-66$ \\
\hline
\end{tabular}

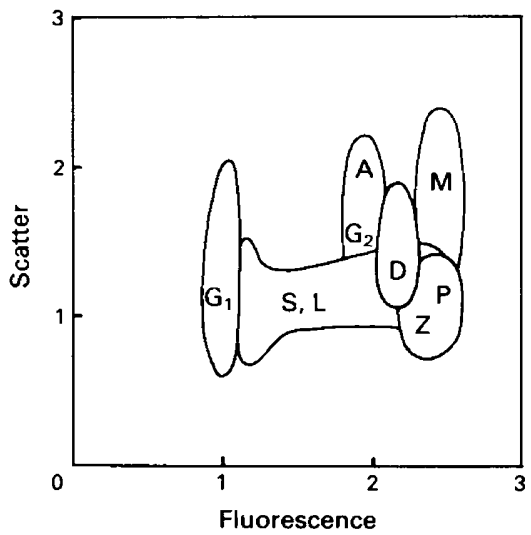

Fig. 2. Diagram illustrating the fluorescence and forward light scatter distribution of various stages in the meiotic and mitotic cell division, based on cell sorting experiments with the FACS IV on ethanol and formaldehyde/glutaraldehyde-fixed and mithramycin-stained suspensions of ovarian cells of neonatal rabbits (Table 1). $\mathbf{S}=$ DNA-synthesis phase, $\mathbf{M}=$ mitosis, $\mathrm{L}=$ leptotene, $\mathrm{Z}=$ zygotene, $\mathrm{P}=$ pachytene, $\mathrm{D}=$ diplotene, $\mathrm{A}=$ aggregating interphase cells $\left(\mathrm{G}_{1}\right.$ doublets $)$.

corresponded to an increase in advanced meiotic prophases. When the $2 \mathrm{~b}$ fraction was compared with the fraction of zygotene + pachytene + diplotene steps $(Z+P+D)$ there was a moderate linear correlation $(r=0.79, P<0.001, n=14)$. If mitotic figures $(\mathrm{M})$ were included $(\mathrm{Z}+\mathrm{P}+\mathrm{D}+\mathrm{M})$, the correlation was improved $(r=0.90, P<0.001)$, but further inclusion of the 
Table 2. Fluorescence distribution of ovarian cells of neonatal rabbits, measured by flow cytometry on cell suspensions fixed with ethanol and formaldehyde/glutaraldehyde and stained with mithramycin

\begin{tabular}{lcccccc}
\hline $\begin{array}{l}\text { Days } \\
\text { after } \\
\text { birth }\end{array}$ & $\begin{array}{c}\text { No. of } \\
\text { rabbits }\end{array}$ & la & lb & $\mathrm{S}$ & $2 \mathrm{a}$ & $2 \mathrm{~b}$ \\
\hline 3 & 3 & $55 \cdot 6 \pm 4 \cdot 6$ & $17 \cdot 2 \pm 4 \cdot 0$ & $14 \cdot 8 \pm 0 \cdot 4$ & $7 \cdot 0 \pm 1 \cdot 9$ & $5 \cdot 5 \pm 0 \cdot 6$ \\
5 & 6 & $46 \cdot 7 \pm 3 \cdot 1^{\mathrm{a}}$ & $27 \cdot 6 \pm 2 \cdot 5^{\mathrm{b}}$ & $13 \cdot 0 \pm 0 \cdot 6^{\mathrm{c}}$ & $5 \cdot 4 \pm 0 \cdot 4$ & $7 \cdot 4 \pm 0 \cdot 5^{\mathrm{d}}$ \\
8 & 2 & $49 \cdot 4 \pm 0 \cdot 6$ & $15 \cdot 4 \pm 0 \cdot 9$ & $9 \cdot 4 \pm 0 \cdot 6$ & $6 \cdot 0 \pm 0 \cdot 4$ & $20 \cdot 0 \pm 1 \cdot 2$ \\
9 & 9 & $56 \cdot 9 \pm 2 \cdot 2^{\mathrm{a}}$ & $9 \cdot 1 \pm 1 \cdot 5^{\mathrm{b}}$ & $8 \cdot 3 \pm 0 \cdot 6^{\mathrm{c}}$ & $5 \cdot 4 \pm 0 \cdot 5$ & $20 \cdot 4 \pm 1 \cdot 6^{\mathrm{d}}$ \\
16 & 2 & $87 \cdot 2 \pm 1 \cdot 1$ & 0 & $3 \cdot 8 \pm 0 \cdot 6$ & $6 \cdot 5 \pm 0 \cdot 2$ & $2 \cdot 7 \pm 0 \cdot 1$ \\
\hline
\end{tabular}

The fluorescence histograms were deconvoluted in fractions as shown in Fig. 1. The fluorescence intensity ratio of peak $1 \mathrm{~b}$ relative to peak la varied within the range $1 \cdot 07-1 \cdot 14$. The fluorescence intensity ratio of the dominating peak in the $2 \mathrm{~b}$ region relative to peak la varied within the range $2 \cdot 14-2 \cdot 35$. CV of peak la was on average $3.8 \%$ (range $3 \cdot 1-4 \cdot 8 \%$ ).

All values are mean \pm s.e.m. based on the variation between individual rabbits. Values at Day 5 and 9 that share a common letter are significantly different: b, c, d, $P<0.001 ; \mathrm{a}, P<0.02$ (Students $t$ test).

Table 3. Distribution of ovarian cells of neonatal rabbits with respect to stage in the meiotic and mitotic cell division

Cell division stage ( $\%$ of cells)

\begin{tabular}{|c|c|c|c|c|c|c|c|c|}
\hline \multirow{2}{*}{$\begin{array}{l}\text { Days } \\
\text { after } \\
\text { birth }\end{array}$} & \multirow{2}{*}{$\begin{array}{l}\text { No. of } \\
\text { rabbits }\end{array}$} & \multirow[b]{2}{*}{ Interphase } & \multicolumn{4}{|c|}{ Meiosis } & \multirow[b]{2}{*}{ Mitosis } & \multirow[b]{2}{*}{ Necrosis } \\
\hline & & & Leptotene & Zygotene & Pachytene & Diplotene & & \\
\hline 3 & 1 & $65 \cdot 8$ & 19.4 & 0 & 0 & 0 & 0.6 & $14 \cdot 2$ \\
\hline 5 & 5 & $80 \cdot 7 \pm 5 \cdot 2^{a}$ & $12 \cdot 8 \pm 4.7$ & $0.5 \pm 0.2^{b}$ & $0.2 \pm 0 \cdot 1^{c}$ & $0^{d}$ & $1 \cdot 4 \pm 0.6$ & $4 \cdot 5 \pm 1 \cdot 5$ \\
\hline 8 & 1 & 61.9 & $10 \cdot 4$ & $12 \cdot 5$ & $10 \cdot 8$ & $3 \cdot 4$ & & 0 \\
\hline 9 & 7 & $60 \cdot 6 \pm 1 \cdot 9^{a}$ & $10 \cdot 6 \pm 2 \cdot 6$ & $7 \cdot 6 \pm 2 \cdot 3^{b}$ & $8 \cdot 1 \pm 1 \cdot 8^{c}$ & $1 \cdot 9 \pm 0.6^{d}$ & $3 \cdot 4 \pm 1 \cdot 5$ & $7 \cdot 8 \pm 1 \cdot 8$ \\
\hline
\end{tabular}

Differential countings in microscope on haematoxylin/eosin stained smear preparations of ethanol and formaldehyde/glutaraldehyde fixed cell suspensions prepared from the ovaries.

Values of Day 5 and 9 are mean \pm s.e.m. based on variation between individual rabbits. Values that share a common letter are significantly different: a, c, $P<0.01 ; \mathrm{b}, \mathrm{d}, P<0.05$ (Students $t$ test).

leptotene (L) stage $(\mathrm{L}+\mathrm{Z}+\mathrm{P}+\mathrm{D}+\mathrm{M})$ weakened the correlation $(r=0 \cdot 75, P<0 \cdot 01)$. If the data from 8-9-day-old ovaries with $\leqq 1.0 \%$ mitotic figures were selected, the correlation between the $2 \mathrm{~b}$ fraction and the meiotic $\mathrm{Z}+\mathrm{P}+\mathrm{D}$ fraction was excellent $(r=0.99, P<0.01, n=5$; Fig. 5).

The leptotene cells were distributed with fluorescence intensities in the range of $1 \cdot 1-2 \cdot 5$ times peak la fluorescence (Figs $1 \& 2$ ). This means that the DNA replication step before meiotic division occurred after the germ cells had morphologically entered the leptotene stage. Preleptotene condensed cells were located in the $1 \mathrm{~b}$ peak. The distribution of oogonia within the $1 \mathrm{a}-1 \mathrm{~b}$ region could not be quantitated, because oogonia were undistinguishable from the somatic cells in these preparations.

The relative increase in fluorescence intensity corresponded to the degree of chromosome condensation. Most fluorescent were the mitotic stages (2.4-2.8 times peak la fluorescence) and the most condensed meiotic prophase stages zygotene and pachytene $(2 \cdot 2-2 \cdot 5$ times peak la fluorescence), whereas cells in the diplotene stage, in which the chromosomes decondense, had only slightly increased fluorescence $(2 \cdot 1-2 \cdot 3$ times peak la fluorescence). 


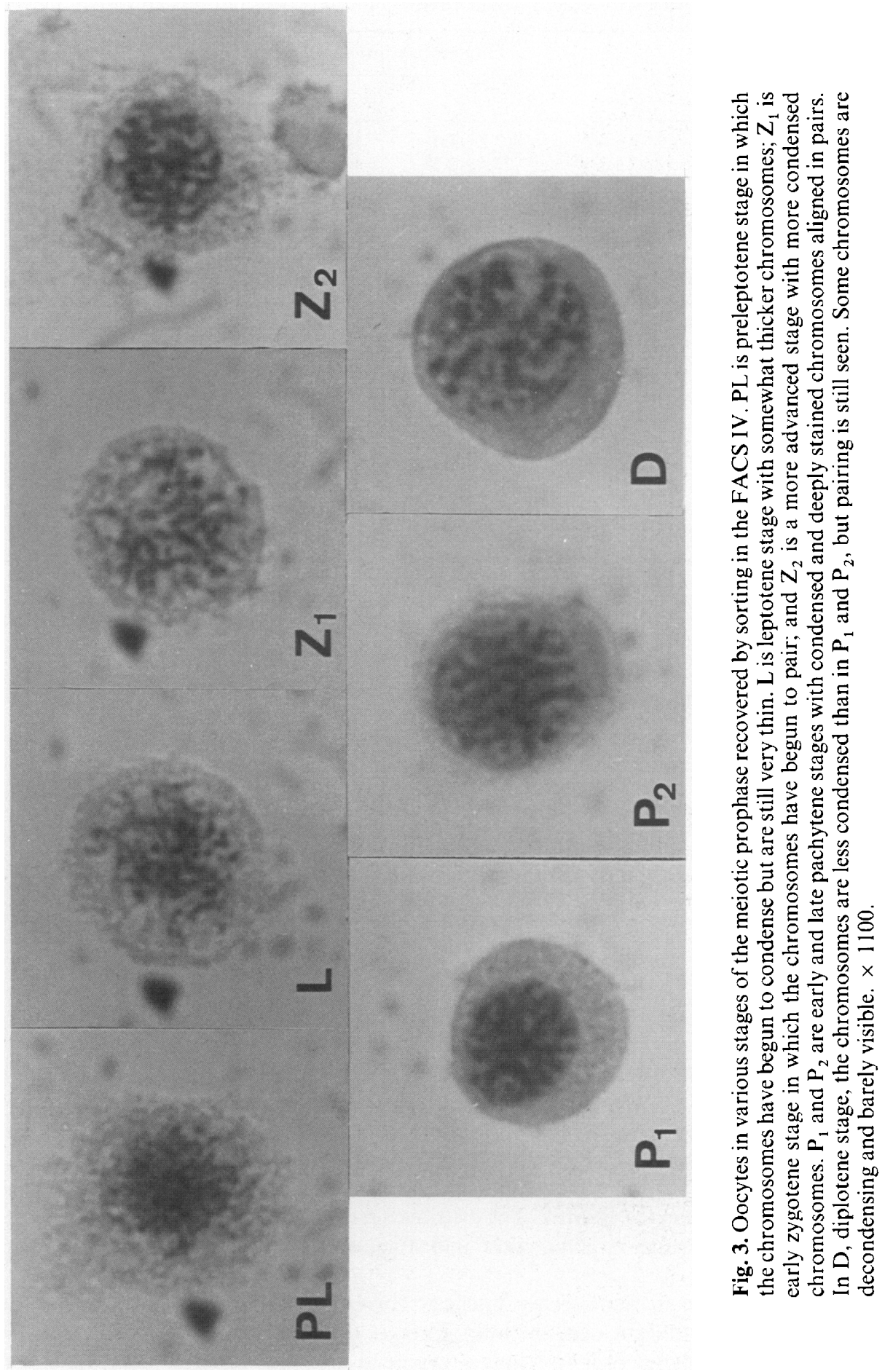




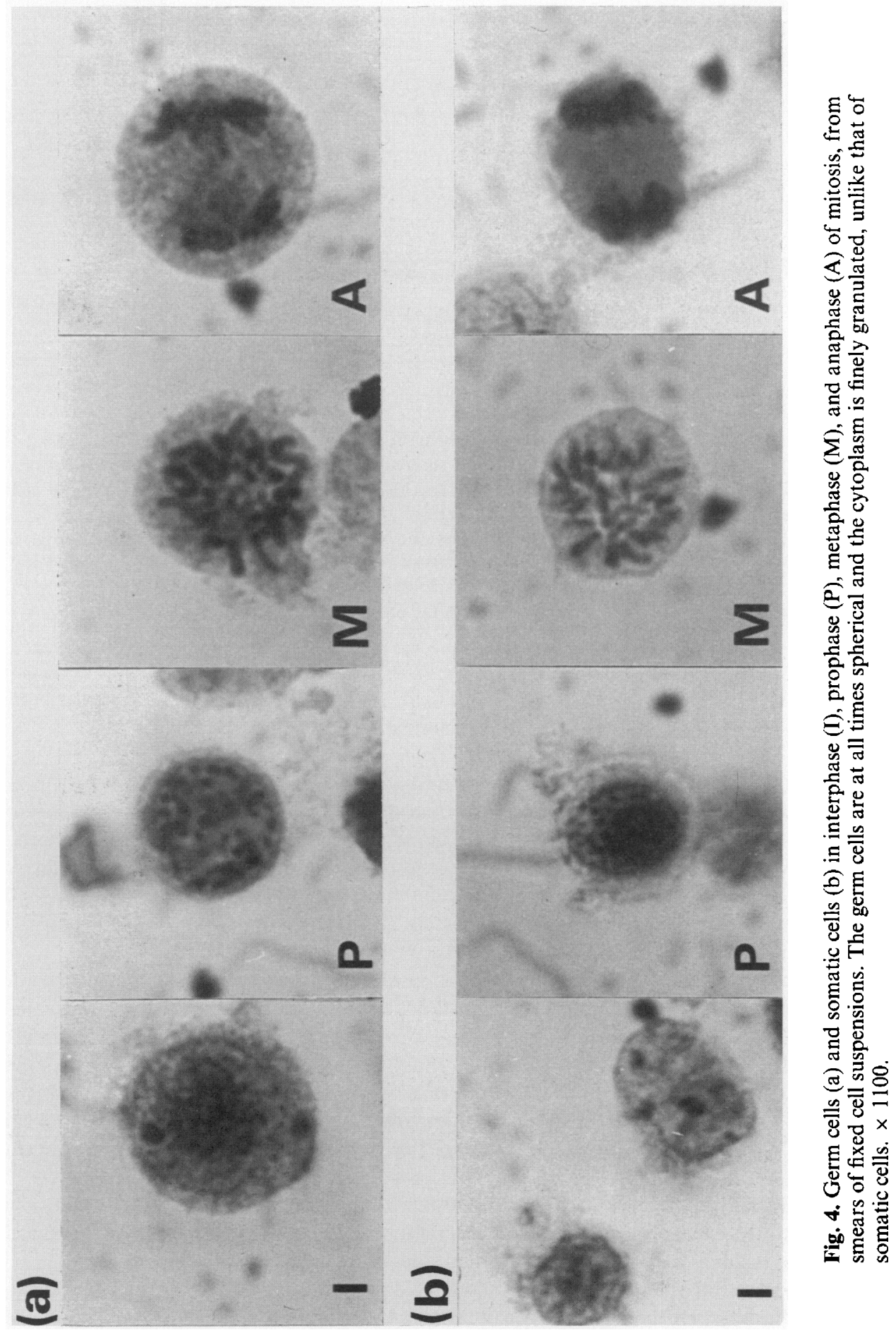




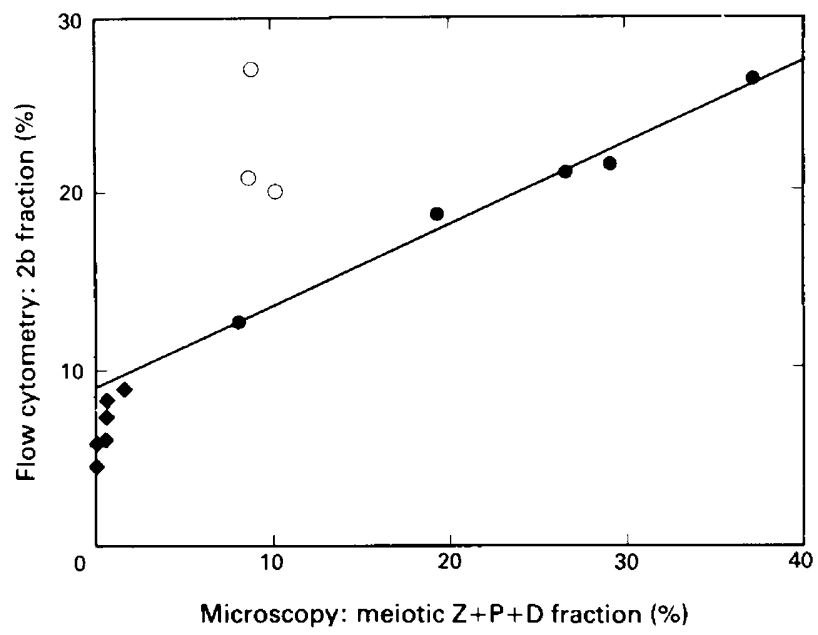

Fig. 5. Comparison between estimates obtained with the flow cytometer and the microscope of the fraction of late meiotic prophase stages in suspensions of ovarian cells of neonatal rabbits. The fraction of ethanol and formaldehyde/glutaraldehyde-fixed and mithramycin-stained cells with fluorescence $\geqq 2.05$ times $G_{1}$ peak intensity ( $2 b$ fraction, ordinate) is compared with the fraction of zygotene + pachytene + diplotene stages, counted with the microscope in haematoxylin/eosin-stained smears of the fixed cell suspensions $(Z+P+D$ fraction, abscissa). $\bullet, 3-5$ days after birth, 0.6-3.8\% mitotic figures;, $8-9$ days after birth, $0 \cdot 0-1 \cdot 0 \%$ mitotic figures; $O, 9$ days after birth, $4 \cdot 2-9 \cdot 3 \%$ mitotic figures.

\section{Discussion}

Quantifying the onset of meiotic prophase in rabbit ovaries is facilitated by a new, automated method, based on combined measurement of forward light scatter and mithramycin fluorescence. The forward light scatter reflects cell size and shape and mithramycin fluorescence reflects both nuclear DNA content and degree of chromosome condensation. Addition of the light scatter parameter to the fluorescence parameter allows the discrimination between different stages of the meiotic prophase (different fluorescence intensities, low light scatter), and mitotic stages (high fluorescence, high light scatter).

In a flow cytometric study on the discrimination of mitosis in nuclear suspensions of lymphocytes and ascites tumour cells fixed and stained with mithramycin, it was demonstrated that the increased fluorescence of mitotic figures was localized in the nucleus, i.e. the chromosomes, and that it depended on the fixation with aldehyde, primarily formaldehyde (Larsen, Munch-Petersen, Christiansen \& Jørgensen, 1986). The heterogeneity in staining was not seen without fixation or with ethanol alone, and was therefore not comparable with the spurious aneuploid peaks of ethanol-fixed and mithramycin-stained lymphocytes as reported by Cunningham, Skramstad, Newburger \& Shackney (1982).

It was also found by Larsen et al. (1986) that relatively increased fluorescence of mitotic nuclei could be obtained with propidium iodide or ethidium bromide instead of mithramycin. These fluorochromes might also be used for differential staining of meiotic prophase cells.

Our demonstration of leptotene cells in the $\mathrm{S}$ region of the mithramycin fluorescence histogram supports the finding of Peters et al. (1965) that DNA synthesis is extended from interphase into leptotene, based on their observation that early leptotene rabbit oocytes label intensely with tritiated thymidine, whereas later stages do not label. Also in human spermatogenesis, the 
premeiotic DNA synthesis is extended into the leptotene and even the zygotene stage (Limade-Faria, German, Ghatnekar, McGovern \& Andersen, 1968). Using spectrophotometry, Swift (1950) concluded that in the plant Tradescantia the main part of the DNA duplication occurred in the leptotene stage. In the study of lily microsporocyte formation, Roth \& Ito (1967) used deoxyadenosine as an inhibitor of DNA synthesis and concluded that DNA synthesis is required in late leptotene or early zygotene to initiate the formation of the synaptonemal complex. The DNA synthesis occurring in leptotene and zygotene is therefore for completion of the premeiotic DNA replication and is different from the repair type of DNA synthesis produced in pachytene, associated with recombination of chromatids in crossing over (Hotta, Ito \& Stern, 1966).

The flow cytometric measurements of acriflavin-Feulgen fluorescence in mouse testicular cells and nuclei by Meistrich et al. (1978) clearly demonstrated a heterogeneity greater than that due to DNA content. Flow cytometry of nuclei fractionated by centrifugal elutriation indicated that late pachytene spermatocytes were more fluorescent than early primary spermatocytes. Flow cytometric measurements on human testicular tissue in our own laboratory (J. K. Larsen, A. G. Byskov, J. Grinsted, J. G. Berthelsen \& N. Skakkebaek, unpublished), on nuclear suspensions prepared with detergent from fresh tissue and analysed according to the combination of ethidium bromide fluorescence and forward light scattering, showed a distribution in 6-8 compartments: 2 in the haploid, $2-3$ in the diploid, and $2-3$ in the tetraploid region. This indicates that nuclear size as well as chromatin structure provide a basis for discrimination of intact testicular cells. In a recent study of van Kroonenburgh et al. (1985), sorting ethanol-fixed rat testicular cells according to mithramycin fluorescence pulse shape combined with orthogonal light scatter, the resolution of 8 cell compartments is demonstrated. It would be interesting to see whether the present method based on ethanol and aldehyde fixation will extend the resolution obtained by van Kroonenburgh et al. (1985).

A condition for using this method for quantitation of meiotic development in rabbit ovaries, or in ovaries of other species, is that sampling of representative germ cell suspensions can be optimized. When the percentages of ovarian cells in interphase (Table 3) are compared with the much smaller percentages of oogonia given by Peters et al. (1965) and YoungLai \& Byskov (1983), it is clear that the cells of the oogenic line are considerably mixed with somatic cells. Although the present data reflect the dynamics of the meiotic process, they do not necessarily describe the absolute numbers of germ cells in the various stages.

We thank Jette Christiansen, Jette Lise Hansen, Rokaya Sapawi and Knud Jørgensen for skilful technical assistance; Tove Nørager and Lene Ahrenst for typing the manuscript; and Claus Yding Andersen for discussions of the experiments. This investigation was supported by the Danish Medical Research Council (grant no. 512-10130) and the Nordic Insulin Foundation.

\section{References}

Byskov, A.G. (1979) Regulation of meiosis in mammals. Annls. Biol. anim. Biochim. Biophys. 19, 1251-1261.

Byskov, A.G., McNatty, K.P., Westergaard, L., Larsen, J.K., Grinsted, J. \& Peters, H. (1983) Abnormal growth of ovarian antral follicles in breast cancer patients. Fert. Steril. 40, 73-79.

Christensen, I., Hartmann, N.R., Keiding, N., Larsen, J.K., Noer, H. \& Vindelev, L. (1978) Statistical analysis of DNA distributions from cell populations with partial synchrony. In Pulse-Cytophotometry III, pp. 71-78. Ed. D. Lutz. European Press, Ghent.

Clausen, O.P.F., Purvis, K. \& Hansson, V. (1977) Application of micro-flow fluorometry to studies of meiosis in the male rat. Biol. Reprod. 17, 555-560.
Crissman, H.A. \& Tobey, R.A. (1974) Cell-cycle analysis in 20 minutes. Science, N.Y. 184, 1297.

Crissman, H.A., Stevenson, A.P., Kissane, R.J. \& Tobey, R.A. (1979) Techniques for quantitative staining of cellular DNA for flow cytometric analysis. In Flow Cytometry and Sorting, pp. 243-261. Eds M. R. Melamed, P. F. Mullaney \& M. L. Mendelsohn. John Wiley \& Sons, New York.

Cunningham, R.E., Skramstad, K.S., Newburger, A.E. \& Shackney, S.E. (1982) Artifacts associated with mithramycin fluorescence in the clinical detection and quantitation of aneuploidy by flow cytometry. $J$. Histochem. Cytochem. 30, 317-322.

Evenson, D.P., Higgins, P.J., Grueneberg, D. \& 
Ballachey, B.E. (1985) Flow cytometric analysis of mouse spermatogenic function following exposure to ethylnitrosourea. Cytometry 6, 238-253.

Hanks, J.H. \& Wallace, R.E. (1949) Relation of oxygen and temperature in the preservation of tissues by refrigeration. Proc. Soc. exp. Biol. Med. 71, 196-200.

Hotta, Y., Ito, M. \& Stern, H. (1966) Synthesis of DNA during meiosis. Proc. natn. Acad. Sci. 56, 1184-1191.

Karnovsky, M.J. (1965) A formaldehyde-glutaraldehyde fixative of high osmolality for use in electron microscopy. J. Cell Biol. 27, 137A-138A.

Larsen, J.K., Byskov, A.G. \& Grinsted, J. (1981) Growth and differentiation of foetal mouse gonads in culture studied by flow cytometry on nuclear suspensions. Acta path. microbiol. scand. A, Suppl. 274, 178-182.

Larsen, J.K., Byskov, A.G., Yding Andersen, C. \& Christensen, I.J. (1982) Flow cytometry and sorting of female meiotic prophase cells. In Abstracts of Combined International Conference on Analytical Cytology and Cytometry IX and the VIth International Symposium on Flow Cytometry, p. 125. Eds L. Wheeless, K. Goerttler \& J. S. Ploem. Schloss Elmau, Mittenwald.

Larsen, J.K., Munch-Petersen, B., Christiansen, J. \& Jergensen, K. (1986) Flow cytometric discrimination of mitotic cells: Resolution of $M$, as well as $G_{1}, S$, and $G_{2}$ phase nuclei with mithramycin, propidium iodide, and ethidium bromide after fixation with formaldehyde. Cytometry 7 (in press).

Lima-de-Faria, A., German, J., Ghatnekar, M., McGovern, J. \& Anderson, L. (1968) In vitro labelling of human meiotic chromosomes with $\mathrm{H}^{3}$-thymidine. Hereditas 60, 249-261.
Meistrich, M.L., Lake, S., Steinmetz, L.L. \& Gledhill, B.L. (1978) Flow cytometry of DNA in mouse sperm and testis nuclei. Mutat. Res. 49, 383-396.

Peters, H., Levy, E. \& Crone, M. (1965) Oogenesis in rabbits. J. exp. Zool. 158, 169-180.

Pfitzer, P., Gilbert, P., Rölz, G. \& Vyska, K. (1982) Flow cytometry of human testicular tissue. Cytometry $\mathbf{3}$, $116-123$.

Roth, T.F. \& Ito, M. (1967) DNA-dependent formation of the synaptinemal complex at meiotic prophase. $J$. Cell Biol. 35, 247-255.

Swift, H. (1950) The constancy of deoxyribose nucleic acid in plant nuclei. Proc. natn. Acad. Sci. 36, 643-654.

von Kroonenburgh, M.J., Beck, J.L., Scholtz, J.W., Hacker-Klom, U. \& Herman, C.J. (1985) DNA analysis and sorting of rat testis cells using twoparameter flow cytometry. Cytometry 6, 321-326.

Vindeløv, L.L., Christensen, I.J., Jensen, G. \& Nissen, N.I. (1983) Limits of detection of nuclear DNA abnormalities by flow cytometric DNA analysis. Results obtained by a set of methods for samplestorage, staining and internal standardization. Cytometry 3, 332-339.

Westergaard, L., McNatty, K.P., Christensen, I., Larsen, J.K. \& Byskov, A.G. (1982) Flow cytometric DNAanalysis of granulosa cells aspirated from human ovarian follicles. A new method to distinguish healthy and atretic follicles. J. clin. Endocr. Metab. 55, 693-698.

YoungLai, E.V. \& Byskov, A.G. (1983) Relationship of meiotic prophase and ornithine decarboxylase in the neonatal rabbit ovary. Cell Tissue Res. 231, 565-570.

Received 7 June 1985 